\title{
Saltwater and bush in New Georgia, Solomon Islands: Exchange relations, agricultural intensification and limits to social complexity
}

\author{
Tim Bayliss-Smith, Matthew Prebble and Stephen Manebosa
}

\section{The wet and the dry in Island Melanesia}

Before European contact and its various effects, the cultivation of taro (Colocasia esculenta) was widespread in Island Melanesia. Taro was grown alongside yams, bananas and vegetables in dryland swiddens, and also in irrigated or wetland sites (Rivers 1926:264). Matthew Spriggs (1990:175) divided the ecological contexts for wetland cultivation into (1) swampland cultivation, where water tables were lowered by digging drainage ditches, which enabled taro to be cultivated in 'island beds'; (2) pit cultivation to tap ground water, a practice developed mainly on coral islands and atolls; and (3) true irrigation in which water was diverted to fields by canals or pipes, being delivered to the crop by simple flooding, in furrows, within pondfields or by flowing around island beds.

It was true irrigation that was often noted by early European visitors like de Queirós in Santo, Vanuatu (Purchas [1625] 1906:221-225; Spriggs 2012; Yen 1976). Although irrigation and water control was extensive on Santo, Rivers (1926:265-266) noted that these practices were not universal in the islands, being sometimes absent even where streams or springs were abundant. Today in Vanuatu, dryland cultivation in swiddens is much more widespread than wetland management (Kirch 1994; Weightman 1989:88), and everywhere disease problems have resulted in a massive decline in taro and its replacement in the diet by sweet potato, cassava and purchased grain foods (Bourke 2012).

\section{Irrigated taro in Solomon Islands}

Rivers $(1926: 269,283)$ noted that irrigated taro in Solomon Islands was 'extensive' on Kolobangara but altogether absent from other islands; for example Santa Isabel and Guadalcanal. This patchy distribution in the post-contact period has been confirmed by later scholars, although parts of north Guadalcanal were a different landscape when Mendaña visited in 1568 (Amherst and Thompson 1901:306; Roe 1993, 2000). 


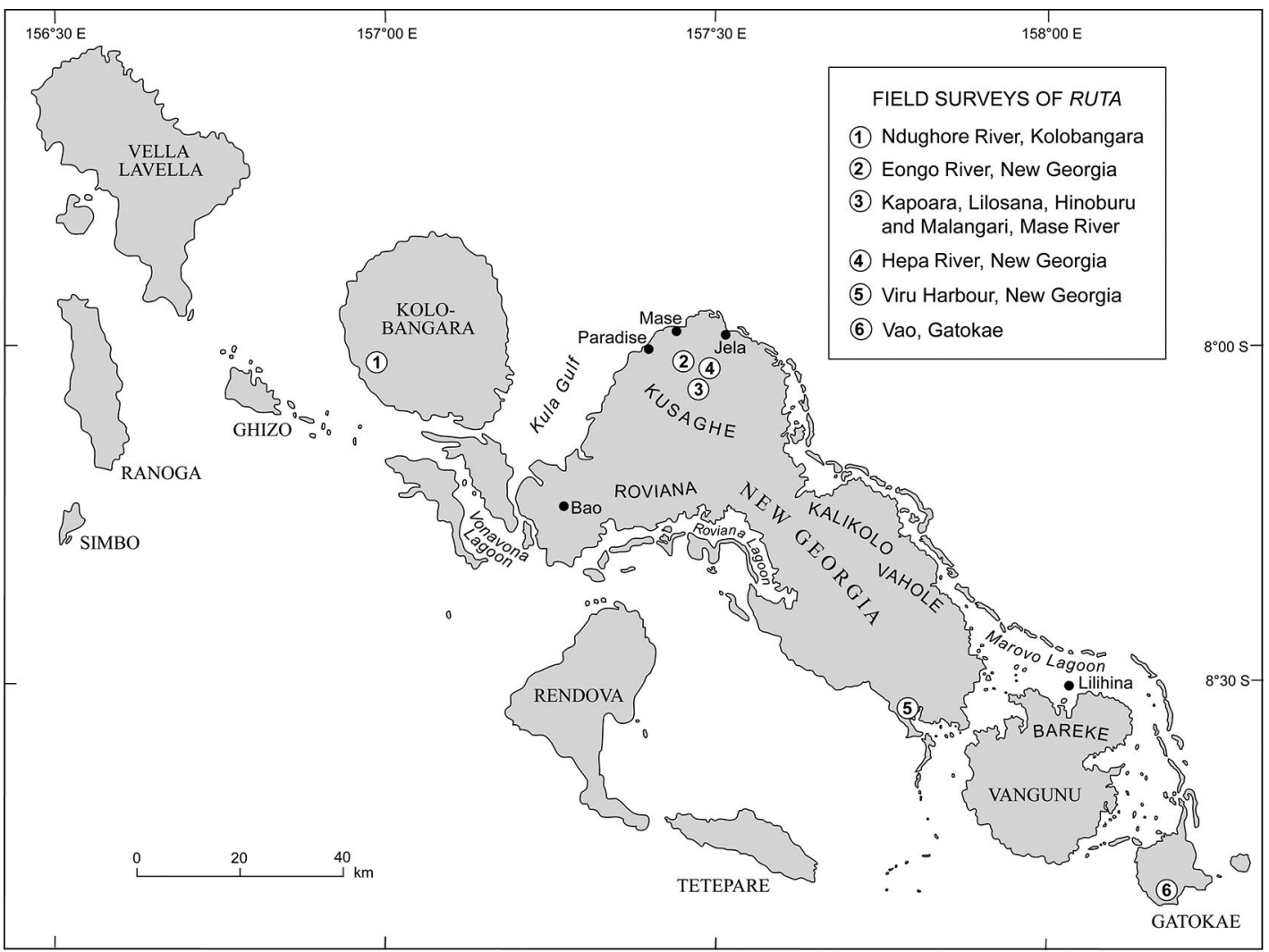

Figure 3.1. Localities in the western Solomons where terraced irrigated taro (ruta) has been reported and surveyed.

Source: Tim Bayliss-Smith, using the following data sources: (1) Kolobangara-Yen 1976, 2009; Scales 2003; (2) and (3) Kusaghe, Eongo and Mase-M Tedder with Barrus 1976; Bayliss-Smith and Hviding 2015; this paper; (4) Kusaghe, Hepa-J Tedder 1968; (5) Viru Harbour-Miller 1979; (6) Gatokae-Bayliss-Smith and Hviding 2012, 2014, 2015.

Cultivation using irrigated terraces was a practice most fully developed in the New Georgia group and Kolobangara, but may have been present on other islands (Bayliss-Smith and Hviding 2012, 2014, 2015; Bayliss-Smith et al. 2003; Hviding and Bayliss-Smith 2000; M Tedder with Barrus 1976). The map showing known sites with terraced irrigated taro (ruta) is based on published records and no doubt could be extended through oral testimony or fieldwork (Figure 3.1).

In the 1960s abandoned systems of taro terracing were reported in the western Solomons, especially Kolobangara and the New Georgia group (Miller 1979). In the interiors of these large forested islands, reports described a relict landscape of terraced pondfields, stone-backed terraces and irrigation channels (Chikamori 1966). It appeared that valley cultivation had been linked to settlements on nearby ridgetops and to sacred sites with megaliths or standing stones (J Tedder 1968). In some places logging, mineral prospecting and field surveys began to reveal widespread evidence for a substantial bush population (Page 1964).

Margaret Tedder in 1974 and Susan Barrus in 1975 carried out surveys of the Mase Crater in north New Georgia, combining their maps and observations in a joint publication (M Tedder with Barrus 1976). As well as taro grown mostly in irrigated terraces, their informants mentioned several other sources of plant food including nuts from Canarium groves, wild bananas, wild yams, and cultivated bananas and sugar cane from swiddens. Already it was too late to recover much oral history, as the old men had been small boys when the last of the Mase ruta had been abandoned in 1917 after the surviving population all moved down to coastal villages such as Paradise, Mase and Njela (Jela). 
The fieldwork of Tedder and Barrus focused on the upper basin of the Mase river, in the area they called 'Old Kusaghe'. They surveyed in detail two complete ruta systems and mapped the total extent of ruta in the Mase Crater. They recorded 15 settlement sites marked by house platforms and standing stones, and connected by graded 'roads' $2-5 \mathrm{~m}$ wide. They also discovered rock art and sacred sites containing skull shrines, shell valuables (poata) and, on occasion, evidence for 19th-century trade goods such as clay pipes, a musket and blue-figured glazed pottery. Ceremonial feasting with taro puddings was suggested by the discovery at Kokorapa of a large, upturned, canoe-shaped food bowl (horete) in a rotten state, within a rock shelter that also contained skulls, shell valuables and some trade goods. The food bowl was said by informants to have been 'used to bring taro and ngali nut pudding ... as an offering to the spirits' (M Tedder with Barrus 1976:83).

Tedder and Barrus estimated that the total area in Mase Crater with ruta terracing was 100 hectares, requiring work inputs from a substantial population. From her work in the archives of the British Solomon Islands Government, Tedder knew that the whole region experienced severe depopulation in the decades before and after 1900. Pioneer missionary Rev. JF Goldie told the Phillips Land Commission in 1923 that after migrating to the coast in 1917, the surviving population of Kusaghe District numbered only 300 people. Goldie estimated that in the past each inland village had 40-50 inhabitants, which suggested to Tedder a former bush population of about $600-750$ people (M Tedder with Barrus 1976:47).

Our maps now show at least 19 sites of villages in the Mase Crater. Of course, the population of each could have been larger than '40-50 people' if numbers in the 19th century were already being affected by depopulation. Tedder calculated the total area of the Mase basin was $24 \mathrm{~km}^{2}$ and she estimated that about one third was potentially arable land. Using multipliers for the carrying capacity of taro swiddens derived from Barrau (1958) and Brookfield with Hart (1971), she estimated that taro cultivation on this land could have supported at least 1000 people (M Tedder with Barrus 1976:48).

Using vegetation maps based on 1960s aerial photography, these estimates could be tested further (Bayliss-Smith et al. 2003). In the Kusaghe area the various 'disturbance forests' that had been mapped totalled $10.2 \mathrm{~km}^{2}$ in area. With an assumed economy of swiddening and using conservative assumptions for yield and fallow length, this land could have supported a population of 1100 . The calculated number rises to 2400 people if one assumes 10 per cent of the disturbance forests were once under wet taro, cultivated more intensively than swiddens and without fallow periods. A population of 2400 implies an overall density of 7.5 persons per $\mathrm{km}^{2}$, a density comparable to populations in inland areas of south Bougainville and north Malaita in the mid-20th century (Bayliss-Smith et al. 2003:350).

\section{Ruta in the Eongo Valley}

We now turn to field evidence for the layout and functioning of one particular ruta system along the Eongo River, north New Georgia, based on our joint fieldwork in 2016. The whole Eongo Valley has been logged in recent years by Pacific Everest Company and some ruta have been damaged or destroyed, but enough evidence survives to show that taro terraces once extended from the Eongo's headwaters to its confluence with the Mase. We hope that our excavations from two ruta sites in the upper Eongo and another site in the Mase Crater will provide inferences about the building of ruta walls, the control of water and connections to nearby habitation sites. Here we focus on the physical evidence that survives at Eongo Ruta 1 and 2 (altitude $450 \mathrm{~m}$ ), with two radiocarbon dates that provide insights about when this landscape of intensification was first initiated. 


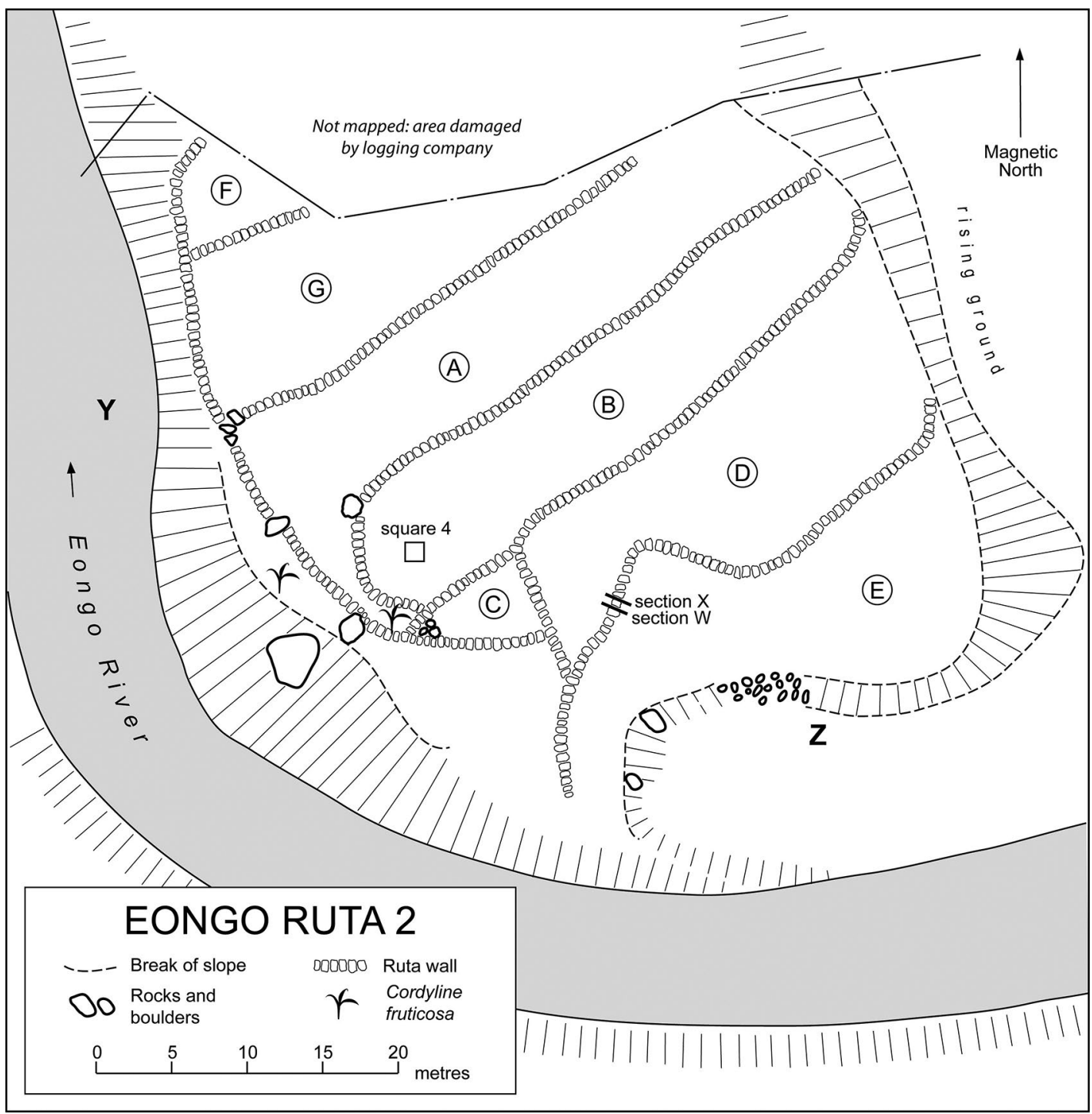

Figure 3.2. Eongo Ruta 2 showing the seven pondfields surviving after damage by loggers, and the location of the first excavation (Square 4).

Source: Stephen Manebosa, field mapping, redrawn.

We have analysed the stratigraphy of seven $1 \times 1 \mathrm{~m}$ squares that we excavated at these two sites, plus the evidence from adjacent river banks and cores taken in ruta pondfields. These all provide evidence for forest clearance in the Eongo catchment with peaks on at least two separate occasions. A side effect of clearance was the deposition of alluvial gravel, sand, silt and charcoal on the river terrace. The sediments were spread by overbank flooding and resulted from accelerated erosion in the Eongo headwaters. At a later stage, ruta walls were constructed on both sites, some of which are visible today, and the flow of water between adjacent pondfields was regulated (Figure 3.2).

It may be possible to match the history of Eongo forest disturbance to the chronology of climate change, in particular the lower rainfall experienced during the Little Ice Age, a period which began around $1300 \mathrm{CE}$ and peaked in the 18th century. Since that time the western Solomons has experienced higher and less seasonal rainfalls, as shown by ongoing work on lake cores from Rendova (Prebble ms.). In the current rainfall regime it is difficult to imagine forest clearing and burning being possible in the New Georgia bush except sometimes during El Niño episodes. 


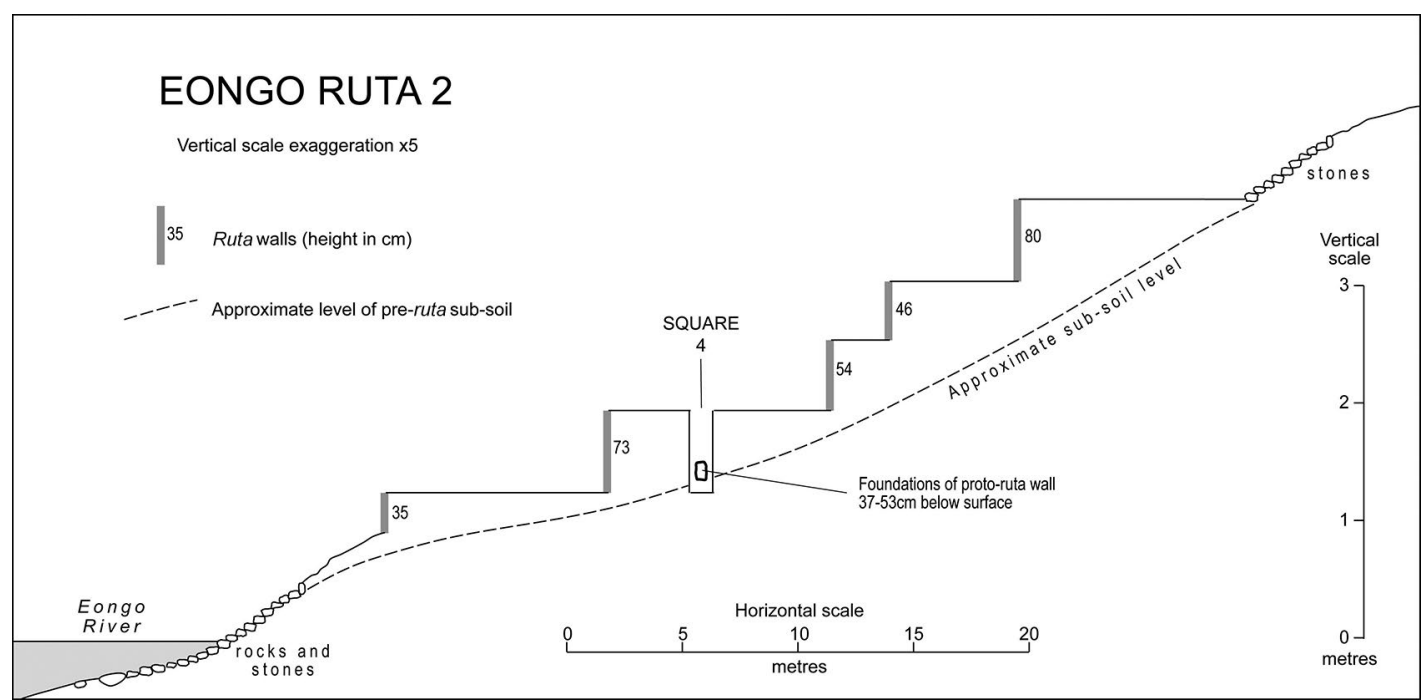

Figure 3.3. Cross-section through five pondfields in Eongo Ruta 2, from point $Y$ to point $Z$ in Figure 3.2 . The vertical scale is exaggerated five times. Excavation in Square 4 revealed part of the buried linear feature shown in Figure 3.5. Source: Tim Bayliss-Smith, field mapping.
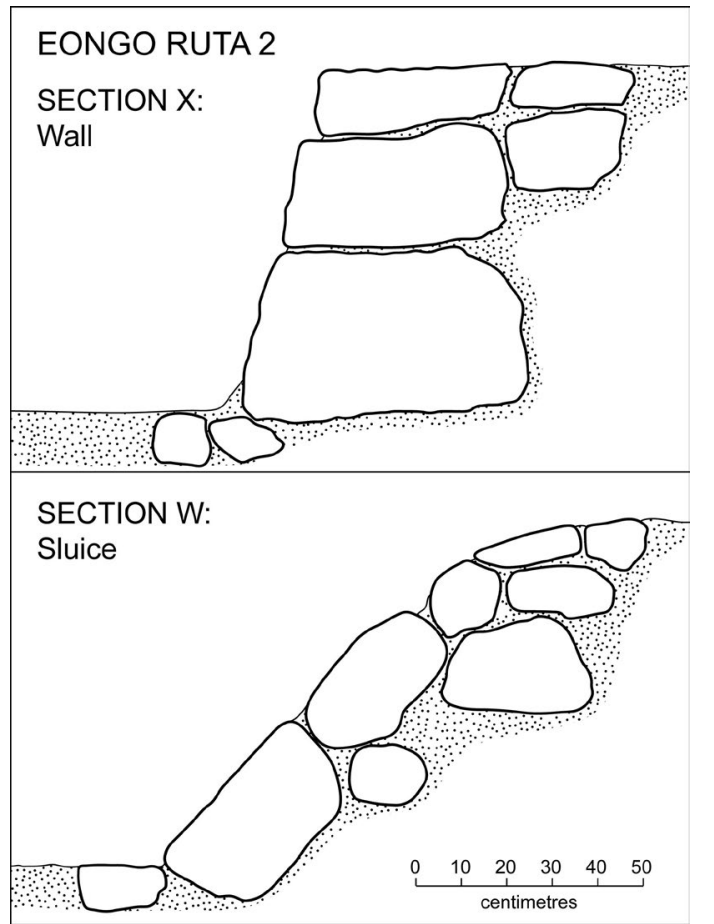

Figure 3.4. Cross-sections through the ruta terrace walls at points $W$ and $X$ of Eongo Ruta 2 (see Figure 3.2).

The wall at $X$, like most ruta walls, is almost vertical (75-80 degrees), whereas at the overflow (section $W$ ) the gradient of the sluice is 52 degrees from the horizontal. Its design minimises the erosive impact of the water overflowing from pondfield $E$ to pondfield $D$, with a fall of $0.75 \mathrm{~m}$ from one level to the next.

Source: Tim Bayliss-Smith, field mapping.
A cross-section through Eongo Ruta 2 shows stone-built terrace walls up to $1.1 \mathrm{~m}$ high separating adjacent pondfields (Figure 3.3). Overflow channels or sluices were constructed in some walls to control the flow of water between adjacent pondfields. When drawn in cross-section, one well-preserved example shows the care that was taken to prevent surplus water from flowing over the wall thereby eroding or undermining it (Figure 3.4). Whereas the main terrace walls mostly rise at an angle of 75-80 degrees from the horizontal, at the overspill or sluice the wall rises more gently at 52 degrees. At its base the overflowing water was channelled on to flat stones in order to further reduce its erosive potential.

The four squares excavated in Eongo Ruta 2 all revealed a linear feature running parallel to the ruta walls that are visible above ground today. We interpret this linear feature as the remains of a former wall now buried $0.4 \mathrm{~m}$ beneath the silty clay soils of the ruta pondfield and dating from an earlier phase of ruta construction. After it was abandoned most of the stones of the earlier wall were re-used elsewhere, but some foundation stones were left in place. Stones from this earlier terrace wall were probably used in the construction of a new and higher wall $2 \mathrm{~m}$ further downslope, thus extending the area of the pondfield (Figure 3.5). 
Radiocarbon dates on charcoal recovered from below this 'proto-ruta' feature, and from lower soil levels below the major phase of colluvial input, help us to constrain the chronology of these events (Figure 3.6). Fragments of charred Canarium nut came from bulk sieved samples excavated from Spit 6 $(50-60 \mathrm{~cm})$ and Spit $8(70-80 \mathrm{~cm})$ from the west wall of Square 4. As the section drawing shows, these samples effectively bracket the construction of the abandoned wall of the proto-ruta. The AMS (accelerated mass spectrometry) date on Spit 8 is $693+/-26$ years $(1267-1385 \mathrm{cal} \mathrm{CE})$, and from Spit 6 is $638+/-24$ years $(1286-1394 \mathrm{cal} \mathrm{CE})$.

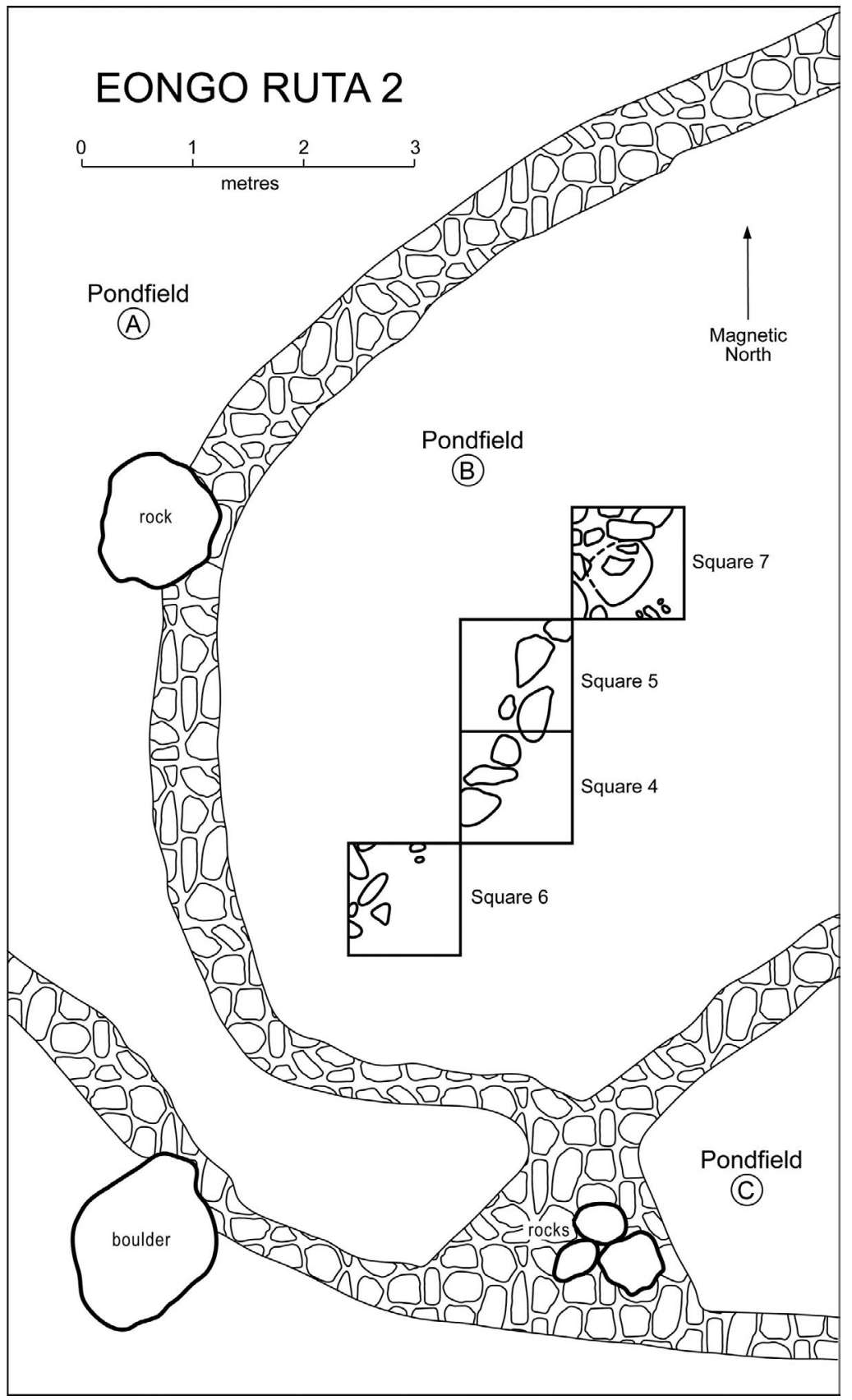

Figure 3.5. Detail of the map of Eongo Ruta 2 showing a buried linear feature that we interpret as the foundations of a 'proto-ruta' wall.

Radiocarbon dating of the charcoal-rich horizon that underlies this feature enables us to date its initial construction to the 14th century CE (see Figure 3.6).

Source: Stephen Manebosa, field mapping. 
EONGO RUTA 2, SQUARES 4 \& 5, WEST FACE Scale 1:10

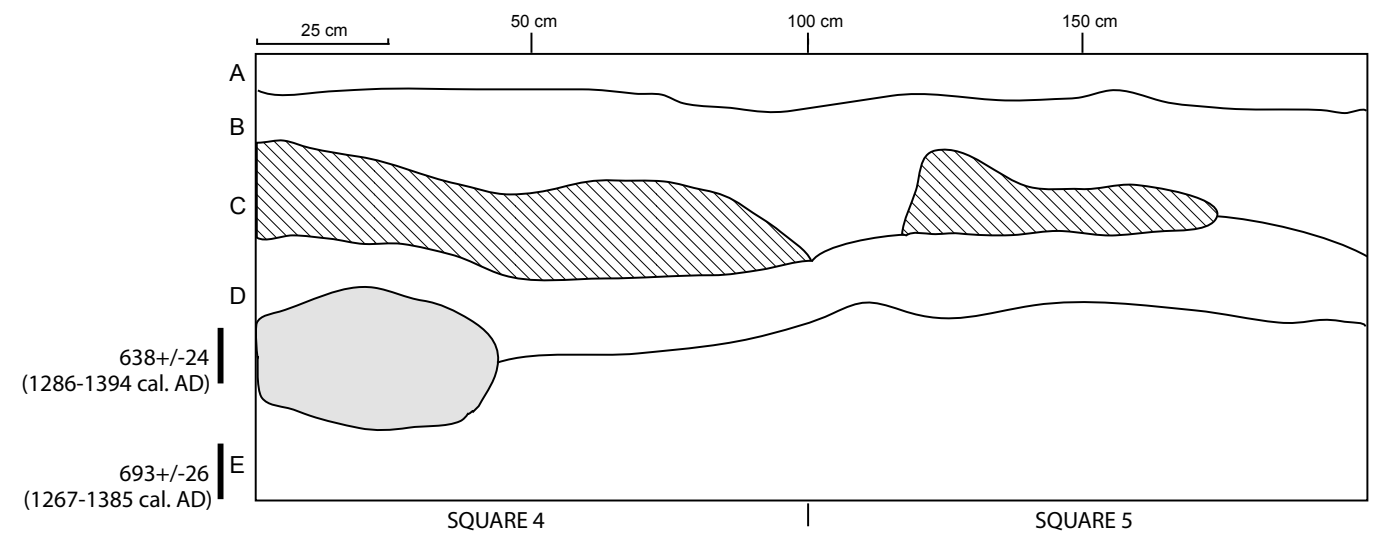

A. 0-7 cm Light brown clayey silt with abundant small roots

B. 7-20 cm Brown clayey sandy silt with abundant small roots

C. $20-33 \mathrm{~cm}$ Reddish brown sandy silt with charcoal

D. $33-47 \mathrm{~cm}$ Light brown clayey silt with some charcoal

E. 47-80 cm Dark-brown silty clay with charcoal

Excavation ceased before reaching bedrock

Figure 3.6. West-face stratigraphic diagram of the Eongo Ruta 2 Squares 4 and 5, showing two similar AMS dates based on charred Canarium nut from bulk sieved samples taken from Spit $6(50-60 \mathrm{~cm})$ and Spit $8(70-80 \mathrm{~cm})$.

S-ANU\# 55010 provides a date for Spit 8 and S-ANU\# 55011 for Spit 6. These two dates indicate the construction of the proto-ruta was in the 14th century CE.

Source: Matthew Prebble, field survey, with details added of the two AMS dates.

If we generalise to Eongo Ruta 2 as a whole, this terraced agricultural system was probably constructed in the 14th century CE. If so, then it pre-dates several coastal sites associated with the expansion of the Roviana chiefdoms in south-west New Georgia (Aswani and Sheppard 2003). Eongo Ruta 2 appears instead to be contemporary with the large earth platforms faced with basalt slabs that are found on the Bao ridge inland from Roviana. These platforms belong to the so-called Bao Period of 1200-1550 CE and are described today as shrines used in rituals of land clearance and fertility, being associated with speakers of the now extinct Kazukuru language (Thomas 2009:123; Walter and Sheppard 2006). The earliest of the ones excavated is Site 145 on the Bao ridge, $4 \mathrm{~km}$ inland from the lagoon and about $160 \mathrm{~m}$ above sea level. All these sites are situated some distance from the presumed habitation and gardening zones (Walter and Sheppard 2017:142). Apart from the Bao shrines, prior to our fieldwork in the Kusaghe region of north New Georgia no inland sites had been excavated or dated.

We have no information yet about the date of abandonment of the Eongo River ruta system, but it may be significant that we found still growing by the riverside nearby several plants of feral taro (Colocasia esculenta). On the site itself there were two zipolo plants (Cordyline fruticosa), still planted today in gardens for their spiritual qualities. These plants must be survivors from the last time this site was cultivated, possibly in the late 19 th or early 20 th century. 


\section{The ethnography of ruta on Kolobangara}

The first written account of ruta in cultivation comes not from New Georgia but from the neighbouring island of Kolobangara, where a young English anthropologist Arthur Hocart spent two weeks in December 1908 based at Ghatere. With his Ghatere guides Hocart walked inland to Aghara to see taro cultivation in walled pondfields called lologha, a word translated by Hocart as 'Roviana: ruta'. Transcribed by Ian Scales $(2003: 262,334)$, his field notes read as follows:

Ruta. In Aghara beside river that has no name. Ruta consists of a series of terraces about 5 by $10 \mathrm{~m}$ or thereabouts; each terrace about $50 \mathrm{~cm}$ above the other: all dammed with stones through which water trickles. Taro planted in rich mud with about $1 \mathrm{~cm}$ of water upon it. One lot belongs to Pizhaka, another to Tandi.

This appears to be the first and only eye-witness account of ruta in cultivation. Hocart's precise descriptions of the width of pondfields, height of walls and depth of water ('about $1 \mathrm{~cm}$ ') are important details. It would appear that water management required the damming of inlets and outlets and was designed to flood the taro field with just enough water to fertilise the crop and discourage weed growth.

Hocart questioned his guides about the inheritance and ownership of taro pondfields (Scales 2003:262,334). He was told that each ruta was the property of an individual, and once built it became a permanent feature: 'a lologha $[\mathrm{ruta}]$ does not and is never changed'. The taro grown there was replanted immediately after harvest ('the same day'), having taken 13 months to reach maturity (Scales 2003:310). Hocart makes frequent mention of persons from an older generation as being the earlier owners or builders of individual pondfields, and Scales comments that this genealogy 'suggests continuous use of the fields since at least the 1880s' (Scales 2003:262).

Some Kolobangara ruta were probably constructed much earlier than the 1880s. In 1971 Kirch, Rosendahl and Yen surveyed archaeological sites in the Ndugore valley in south-east Kolobangara and obtained charcoal from behind the terrace wall of a ruta built on a tributary stream (Yen 1976:69). The sample was taken from $40 \mathrm{~cm}$ below the soil surface and gave a calibrated date in the range 1630-1820 CE (Yen 2009:173).

In the 1970s all the inland ruta pondfields on Kolobangara were lying abandoned, but all were still claimed in ownership by individuals living in the coastal villages (Yen 1976:70). Today logging has extended across most of the island, and probably most of the archaeological evidence for ruta on Kolobangara has now been damaged or destroyed.

\section{Oral history of ruta in Marovo, New Georgia}

In New Georgia there has also been extensive logging, but in the Mase Crater and elsewhere there is still much field evidence that survives. As on Kolobangara, in New Georgia some knowledge of ruta has been maintained by people now living in coastal villages, although many have never seen the inland sites. Even so, the vocabulary used in New Georgia languages shows that 'taro gardens are different from all other gardens', as the Marovo people explain it (Hviding and Bayliss-Smith 2000:120-122). Terms used for the cultivation of sweet potato (since the late 19th century) and cassava (since the 20th century) were taken from the existing vocabulary for yam cultivation, whereas the distinct vocabulary for taro cultivation, conferring a special status on this crop, was retained.

This distinctive taro vocabulary still remains active, especially among the few people trying to retain or revive ruta cultivation. For example, in Vahole in the 1990s some old couples maintained small relict ruta along tributaries of the Piongo Lavata River (Hviding and Bayliss-Smith 
2000:117). These were merely shallow pools along streams where the water flow was regulated by means of a few logs. The attachment of these people to their ruta was not primarily materialistic, having also an emotional dimension. Taro cultivation was seen as an aspect of a 'good life', the flourishing pondfield and its environs representing a symbolic interconnection between land, water, useful trees and esteemed plant life, all under careful human cultivation to provide the most prized of all root crops. Ruta embodies the practical, the magical and the aesthetic, and thus constitutes the essence of what mana was, and is, supposed to be all about (Bayliss-Smith and Hviding 2012:238).

In the 1990s some of the former practices for making and cultivating ruta could be reconstructed from interviews with old people, for example those from the Bareke Bush in Marovo whom we consulted. According to their testimony, taro was planted in pondfields into which water was led from small streams, the planted beds being surrounded by wooden fences or stone walls to retain the water. The channels thus created were sloping and compartmentalised in order to manipulate the water flow. Generally the ruta that were remembered were quite elaborate constructions with relatively large field spaces devoted to taro plants in three different growth stages, but ruta also existed in the form of smaller fields in places naturally amenable to irrigation. These taro beds needed little modification beyond simple logs for regulating the water flow from the shallow pools found in small tributary rivers and streams. On the Piongo Lavata River the terrace and channel walls were mainly built with stones, but timbers resistant to waterlogging and decay were also needed for ruta construction (Bayliss-Smith and Hviding 2012:238; Hviding and Bayliss-Smith 2000:90).

\section{Oral histories from Kusaghe, New Georgia}

Further information about the former bush diet is available for Kusaghe from Margaret Tedder's interviews in 1974 with the people of Paradise Village. They said that before they moved to the coast, taro and yams were supplemented with meat from feral and domestic pigs, freshwater shellfish, fruits and nuts, especially Canarium spp. Each village or group of hamlets had as its focus a sacred site on a hilltop or ridge where chiefs were buried, with the taro gardens situated in the valleys below. It was said that each family had more than one house and moved up and down the Mase Valley working different gardens (M Tedder with Barrus 1976:48).

Oral histories collected by Hviding suggest that the bush people in Old Kusaghe had exchange and marriage relations with Kazukuru and the coastal people of Roviana to the south, and with the neighbouring bush dwellers of Kalikolo to the east. The Mase Crater provided the Kusaghe with a circumscribed space, but they were not an isolated society. Histories of intermarriage and the existence of several closely related bush languages along the northern slopes of New Georgia indicate a rather homogeneous, inland, taro-cultivating society of wide extent, with solidarity maintained through kinship, exchange and feasts (Bayliss-Smith et al. 2003:350).

The actual techniques of ruta cultivation were described in 1968 by Silas Eto (1968a, 1968b) in two interviews with James Tedder, the District Commissioner. Silas Eto was the 'Holy Mama' or spiritual leader of the Christian Fellowship Church. He was born in 1902 in Hoava, north-west Marovo, but he moved in 1912 to Kolobaghera in eastern Kusaghe before being sent to Goldie College at Kokeqolo and later becoming a Methodist catechist (Aseri Yalangono, interview, Honiara, 26 October 2016).

As a boy Silas Eto would have seen the various operations needed to maintain the family's irrigated taro gardens (ruta). His father Leti, a prominent chief, owned two ruta systems made along streams (ruta bukaha), each having 11 plots. Clearly ruta was a form of cultivation still in 
operation in both of his childhood homes, and the information he gave to Tedder is essentially an eye-witness account. The second interview goes beyond horticultural matters to place ruta into a wider social and cultural context (Eto 1968b).

Silas Eto stated that wet gardens could be divided into two kinds, ruta gineli (terraced fields irrigated from streams) and ruta bukaha (irrigation of flat land on valley floors). A ruta bukaha could be planted and left for a few months 'as they don't need to be looked after', but ruta gineli needed constant maintenance and were therefore always made close to the villages where people lived. A ruta gineli was constructed by digging up the soil to make it soft and by heaping stones into lines forming walled terraces. In this way many separate plots (pondfields) were made for planting. People then dug a trench from a big stream to allow each plot to be irrigated. The plots were very easy to plant, 'just push young shoots down into the mud with your hand or a stick'. When the taro needed water the bottom gate would be closed and the top gate opened to allow water in from the stream, enabling one plot after another to be irrigated, 'filled with water, but not deep'. After three or four days the bottom gate would be opened, every interconnected plot would drain, and then new water would be let in. The ruta gineli was checked morning and evening and if a flood was coming the top gate could be closed. This regime of water management continued until it was time to harvest the taro (Eto 1968b).

In contrast the ruta bukaha that Silas Eto described were on flat land (hapanggala, swampy). Some were constructed close to the villages but often they were made very far distant in the bush'. After planting, a ruta bukaha was sometimes left for 3 to 6 months before being revisited. It could be left untended as the water entered it continually and directly from the flowing stream, not along man-made trenches. A new site would be first cleared of trees, then cleaned up, and then divided by constructing walls: 'each stone boundary was like a path and people could walk on them. On the tops of the stone boundaries people planted betel nut and bananas'. This type of ruta could be filled with water by blocking the lower gate. Later, after harvesting and weeding, it could be cleared of debris by making the stream flow right through the pondfields. After that the top dam was shut again and the ruta could be replanted with taro (Eto 1968a).

\section{The rationale for terraced irrigated taro}

The 'wet' form of cultivation, described by Bareke informants in the 1990s and by Silas Eto in the 1968 interviews, was a technique for taro cultivation that has unknown origins. Our finding that the building of terrace walls in Eongo Ruta 2 took place in the late 13th or 14th century CE suggests a phase of intensification of taro production, but this particular ruta wall may not date the initiation of terracing in the Eongo Valley.

In recent papers Bayliss-Smith and Hviding have tried to explain the origins of ruta within the broader context of exchange, food storage and agricultural intensification in Island Melanesia. They have argued that inland ('bush') populations developed ruta cultivation as a result of their contacts with coastal ('saltwater') populations engaged in predatory inter-island warfare and headhunting. By the late 19th century the relationship had become unequal, especially after coastal groups monopolised access to European trade goods. Arguably these interactions originally took place through a more balanced exchange system in which fish and shell valuables moved inland in exchange for taro, nuts and meat derived from ruta terraces, groves of Canarium trees and hunting respectively. There was also seasonal tribute whereby inland people provided taro for large feasts on the coast. 
Despite its potential for escalation because of ruta's capacity to store and accumulate food energy, the outcome of saltwater/bush exchange was not the growth of population nor the emergence of more centralised polities (Bayliss-Smith and Hviding 2015). Ruta could have been an engine for regional expansion, but instead this system remained a localised and perhaps fragile form of intensification.

While the evidence does not suggest an inexorable process of growth and political expansion, it may be possible to match the onset and intensification of inland ruta to changes in the wider political economy, as reconstructed from archaeological evidence. After c. $1600 \mathrm{CE}$ there were changes in the sacred sites of Nusa Roviana, which became the paramount chiefdom of Roviana Lagoon. The chiefdom of Tusu Marovo in Marovo lagoon probably emerged at this time too. In both cases it is thought that the dramatic expansion of chiefdoms only took place after regular European contact in the 19th century (Thomas et al. 2001). As late as 1900 Kazukuru, the language of the bush people who lived inland of Roviana Lagoon, was still being spoken. It only died out after the last Kazukuru communities moved to the coast, abandoning their inland taro swiddens and ruta (Sheppard et al. 2004:130).

Bayliss-Smith and Hviding (2012) identified various constraints in the western Solomons on the expansion of bush/saltwater exchange based on surplus production from ruta. Elsewhere in the Pacific these interactions between transformed ecology, surplus production and intensified exchange escalated towards the formation of regional chiefdoms and radically transformed landscapes, as in Fiji and Polynesian high islands, but in New Georgia the evidence suggests that an expansion of ruta-based polities was somewhat limited.

According to this argument, three main factors acted in combination to limit growth. Taken together, they can explain the paradox of large islands (for example the New Georgia group) and high potential for expanded production of surplus taro but no evidence for sustained political expansion and centralisation. The three limiting factors are: (1) a diverse cultural geography derived from the mosaic of Non-Austronesian and intrusive post-Lapita peoples and cultures; (2) perpetually unstable politics within a social landscape of persistent inter- and intra-island warfare; and (3) epidemiological constraints, particularly endemic malaria, which made problematic the growth and mobility of population. Acting in combination, we believe these constraining factors encouraged the coexistence of diverse Non-Austronesian and Austronesian languages and cultures, and discouraged the political expansion of any particular group (Bayliss-Smith and Hviding 2012, 2014, 2015).

\section{Inland Kusaghe before its collapse}

Our field evidence from the Eongo River and Mase Crater shows the scale of investment into intensive wet taro production made by bush people, before their society and economy were undermined by the events of the 19th century. The end result was population decline and the eclipse of the inland production system, probably because both its demographic and its sociopolitical rationale had been destroyed by new diseases, new tools and weapons, and new concepts of value. Complete collapse of the bush people's society was signalled by the move to the coast of the few survivors, and their construction of new villages (Paradise, Mase, Njela and others) based on copra as a cash crop and Christianity as a new religion. By 1950, despite being a large and fertile island, New Georgia was mainly covered in rainforest with a sparse population living in small coastal villages. They sometimes visited the extensive forests and mountains of the island's interior for valuable resources like Canarium nuts, wild pigs or timber for canoes, but to the outside world the unknown bush appeared to be largely empty. 
The evidence from Kusaghe suggests that the landscape of the New Georgia bush was very different in the early or mid-19th century. We get some glimpses of coastal communities from traders' accounts of 1844 and 1851 (Bradley 1860:22; Shineberg 1971:305). It seems there were frequent contacts between New Georgians and European whaling and trading ships exchanging turtle shell or food for tomahawks, but these brief encounters are seldom documented. Coastal people obtained from these exchanges the various commodities that Jared Diamond (1997) famously summarised as 'guns, germs and steel', whereas the bush people received these things later, second-hand, or not at all. In Bougainville, for example, Carl Ribbe (1903:96) commented that although the merchandise exchanged by the traders went far into the mountains, moving from tribe to tribe, the transactions became more costly. As a result, bushmen in the interior had to pay the equivalent of 300-400 coconuts for a hatchet that was priced at only 100 coconuts on the coast.

Accompanying this process of marginalisation, by the mid-19th century hostility seems to have become the dominant pattern in bush/saltwater relations. The period after 1850 saw a steady decline in the status of bush communities in the western Solomons. At the same time as their cultures and economies had been marginalised, their populations were being destroyed by disease and warfare. Reflecting their marginal position in the new political economy of colonial contact, Europeans began to describe the cultures of bush people in unfavourable terms, and even denigrated their supposed racial characteristics.

\section{Case study: The Bareke Bush, Vangunu Island}

By the 1880s the 'primitive' character of bush populations in Solomon Islands had become the dominant narrative. The visiting English naturalist Charles Woodford, for example, was at Lilohina Island in Marovo Lagoon in October 1886, where he found himself among the saltwater people living adjacent to the inland settlements of Voge and Vavae on the Bareke side of Vangunu Island. In his diary he combines local information with his own observations and conjectures:

There are abreast of this place [Lilohina Island] several bush villages on the tops of the range while the existence of others is shown by wreaths of smoke. I am told they are a different race and speak another language to the coastal natives, they are probably earlier inhabitants of the island driven inland by the later arriving coast tribes. They and the coast natives hold little communication and the former rarely come down to the coast. Occasionally the coast people capture a head or two from the bushmen. (Woodford 1886)

Only one foreigner, Lieutenant Somerville of the Royal Navy survey ship HMS Penguin, saw life in the New Georgia bush first-hand and recorded his observations. In 1893 Somerville led a surveying party inland on Vangunu, but by travelling with coastal guides along ridgetop paths he was unable to observe the presence of ruta cultivation in the valley floors. In his report to Commander AJ Balfour he stated it was perfectly safe ('for men of war folk at least') to travel into the New Georgia interior 'provided that sufficient warning be given so as not to alarm the bush natives by a sudden appearance in their villages' (Somerville 1893).

Somerville sought to extend his general conclusion to other bush populations in New Georgia, suggesting that:

This small expedition into the bush thus points out that (1) Most of the people of this district live away from the sea coast. (2) That, however, they are probably in the habit of visiting the coast for trade, etc. (Somerville 1893:9)

Oral histories collected by Hviding confirm that there were formerly significant numbers of people in the area that Somerville visited. According to late-20th-century informants they were swidden cultivators but also had irrigated taro (ruta) in the valleys (Bayliss-Smith and Hviding 2012; Bayliss-Smith et al. 2003:250). 
Somerville's theodolite survey station was established on a ridge about $450 \mathrm{~m}$ in altitude and close to a hamlet of six inhabited huts and a large house, but with only three or four old men and women in residence. He was impressed by the evidence of European goods ('pipes, tobacco and trade axes') showing that the bush people made regular visits to the coast for trade (Somerville 1893:6). A majority of the population, he believed, lived inland not on the coast (Somerville 1897). On the Admiralty chart based on the surveys of Somerville and others are marked houses on the ridgetops and plateaus of the Bareke Bush covering those areas where Somerville travelled, but none are marked in areas where he did not travel (Admiralty 1896). Inland there are 23 house symbols marking 11 different sites (i.e. hamlets). The six inhabited huts in the ridgetop hamlet where Somerville's party stopped are represented by two symbols. The chart also marks saltwater settlements. There are 33 house symbols along the adjacent coastline, showing settlements at Repi on the Vangunu Coast (total nine symbols), on Marovo Island (13) and elsewhere. Each site is marked with clusters of up to five symbols, and they are shown in places that match the locations of present-day villages. We can conclude that in the 1890s bush settlements in Bareke were still numerous, but they were smaller in size than the coastal villages.

Somerville's observations from 1893 point to both the separation and the integration of saltwater and bush peoples in this Ulusaghe region of New Georgia. The quality of the footpaths that Somerville followed indicates constant use as well as the ability of bush people to organise substantial labour for the construction and maintenance of what were described as 'roads'. These well-maintained tracks running between seashores and mountain ridges allowed frequent contact between bush and coast, which is consistent with regularised food barter between the two groups. A major item in this barter was the taro produced from irrigated terraces (ruta) in inland valleys.

There are almost no other accounts on which to base an ethnography of these inland populations. All transactions between Europeans and local populations were conducted on the beach or in coastal villages, with saltwater people usually acting as the middlemen. Did the saltwater people often venture inland? It would appear that Somerville's coastal guides were reluctant to do so, an attitude reflected in oral traditions about the dangers posed by special snakes, crocodiles and other creatures of the inner lands, as well as dangers from the local spirits that inhabited certain places (Bayliss-Smith and Hviding 2012).

With the arms trade, headhunting and expanding warfare, few Europeans dared to travel far from the coast, and the incentive to do so was further reduced after 1900 when the few remaining bush populations, already decimated in numbers by warfare and disease, relocated their settlements to coastal sites (Hviding and Bayliss-Smith 2000:149-152). Their declining numbers, diminished political role and isolation from colonial trade removed any incentive to live inland. With the end of endemic warfare around 1900, it became possible for bush people to live in coastal settlements and cultivate coconuts, and thereby to gain direct access to European trade goods.

\section{The wider political economy of bush collapse}

An important factor in the decline of inland populations on New Georgia was the increasing pressure put upon them by coastal chiefdoms, centred on Nusa Roviana and Tusu Marovo. The escalation in headhunting voyages overseas has been attributed to the acquisition in the early 19th century of steel tools, tomahawks and later firearms by certain coastal groups in Simbo, Roviana and Marovo (Hviding 1996; McKinnon 1975). We know much less about the escalating violence between coastal chiefdoms and inland groups, but there are indications that in the 19th century the Roviana chiefs began to have more aggressive relations with their trading partners in the Kusaghe Bush (Aswani and Sheppard 2003:S59). Roviana oral traditions describe conflicts with neighbouring Kusaghe and also disease epidemics, which together persuaded 
another inland group, the Kazukuru, to abandon their inland settlements on the Bao ridge, $4-5 \mathrm{~km}$ inland and above $150 \mathrm{~m}$ in altitude. Roviana traditions say that the Kazukuru migrated southwards and moved to small islands on the coast such as Nusa Roviana.

A Kusaghe perspective on these turbulent events can be gained from the evidence collected by Judge FB Phillips in 1923, in the course of his investigations into the validity of claims to land alienated to foreigners across a wide swathe of coastal land in north New Georgia (Phillips 1923:105-135). The question for Phillips to decide was whether these lands had been occupied and used at the time of the Pacific Islands Company land grab in 1903, and therefore to what extent they were really 'wasteland' suitable for land alienation. In this connection a man called Lai testified that as a child he and all the Kusaghe people had lived in the bush 'at Gegeri, Kusagi, Senga, Harena'. Nggenggere and Sengga (modern spellings) are both places in the Mase Crater. Lai said they did not live on the coast because of headhunting raids especially by warriors from Roviana Lagoon, although they still fished and collected coconuts, for example those planted at Menasakapa, today's Paradise (Phillips 1925:137-154).

These accounts also indicate that warriors from Marovo Lagoon were becoming more aggressive towards their exchange partners in the Kusaghe Bush (Phillips 1923:107-112). The testimony of Lai appears to corroborate Roviana accounts that suggest the Kazukuru people were pushed southwards towards Roviana (Aswani and Sheppard 2003:S59). This movement may perhaps have been the result of epidemics (Roviana oral histories) or perhaps because of defeat and massacre by the Kusaghe from the north (Lai's account). Eventually the Kazukuru intermarried and became absorbed into coastal Roviana groups, and their language later became extinct.

Clearly the 19th century was a time of growing political unrest and escalating violence in New Georgia, continuing up until to 1900 and forcing the Kusaghe to abandon the coast. Increasingly they were confined to remote inland areas, especially the Mase Crater. Perhaps this confinement of bush populations like the Kusaghe to inland areas was one factor that encouraged further agricultural intensification. According to this model the expansion of ruta in the 19th century would be a response to the marginalisation of bush peoples in the new economy of tomahawks, headhunting and copra trading. In order to compete in this brave new world they had to produce more taro from an expansion of their ruta.

\section{Conclusion}

The field evidence from the Eongo River suggest that agricultural intensification in inland New Georgia was a dynamic and sustained process. We have evidence for forest clearance and burning in the past, and on a scale difficult to envisage in the present climate of high and non-seasonal rainfall. It appears that the steep valley-side slopes of the Eongo catchment were subject to widespread slash-and-burn for the purposes of 'dry' swidden cultivation, presumably for yams as well as taro. On less steep slopes with a potential for water supply this clearance phase was followed by an intensification of taro production, involving the construction of stone walls to support terraced pondfields (ruta). In one case that we excavated we see evidence for an earlier wall being reconstructed to enlarge the cultivated area.

It is not valid to interpret the 'rise of ruta' entirely through an understanding of its fall in the decades just before and after 1900, in the face of colonial impacts and opportunities. There were certain unique features of colonialism, such as the epidemics that rapidly undermined the viability of inland societies and their production systems. At the general level of political economy, however, there may be lessons that we can learn from ruta's collapse. 
In particular, it is tempting to see the advantaged position of coastal groups c. 1850, following their privileged access to new trade goods (steel axes, firearms, tobacco), as a suitable analogue for saltwater/bush relationships in earlier times, following coastal innovations in ideology and wealth. By 1600 there is archaeological evidence from Roviana for the building of new types of shrine and the production of new shell valuables, alongside (it is assumed) the emergence of a more ranked saltwater society of paramount chiefs, commoners and slaves (Aswani and Sheppard 2003; Sheppard et al. 2000; Walter and Sheppard 2000, 2017).

Were these coastal innovations around 1300 and/or 1600 a sufficient stimulus for a process inland of agricultural intensification and the expansion of ruta? As an alternative, the reverse scenario is equally possible. Perhaps the real driver of change was the surplus taro that became available from an expanding population living inland in the malaria-free uplands. Was it this food surplus that encouraged saltwater communities to innovate so they could maintain some leverage in these vital bush/saltwater exchanges? Only when we obtain a fuller chronology for the rise of inland ruta can we hope to resolve some of these tantalising questions.

\section{Acknowledgements}

For their help with the fieldwork we thank, in Honiara: Aseri Yalangono, James Bosamata (Ministry of Education), Tony Heorake and Lawrence Kiko (Solomon Islands National Museum); in Gizo: Kenneth George Nginabule, Nixon Tigina and Adrian Toni (Provincial Secretary); in Paradise: Rooseman Ruriti; in Mase: Lidly George, Melva George, Randall Reke and numerous field assistants. For help with archival work in Canberra and Sydney we thank Jean Kennedy, Bernadette Hince, Kylie Moloney, Leela Smith and Bob Debus. Discussions in Cambridge with Edvard Hviding in 2017 and 2018 were also an important stimulus. For administrative and logistic support in the University of Cambridge Department of Geography, we thank Bill Adams, Ash Amin, Danielle Feger, Yasmiena Jones, Chris Rolfe and Philip Stickler. The research by Author \# 1 received financial support from a Leverhulme Emeritus Fellowship, from the Smuts Fund, University of Cambridge, and from St John's College, Cambridge.

\section{References}

\section{Published}

Admiralty. 1896. South Pacific, Anchorages in the Solomon Islands. Surveyed by Commander AF Balfour, HMSS Penguin 1894. 1. New Georgia, Vangunu Island, North and North-east Coast Marovo Lagoon. Map, scale circa 1:75,000. London: British Admiralty.

Amherst, Lord, of Hackney and B Thomson (eds). 1901. The discovery of the Solomon Islands by Alvaro de Mendaña in 1568. Vol. 2. London: Hakluyt Society.

Aswani, S and P Sheppard. 2003. 'The archaeology and ethnohistory of exchange in precolonial and colonial Roviana. Gifts, commodities and inalienable possessions'. Current Anthropology 44 (supplement):S51-S78. doi.org/10.1086/377667.

Barrau, J. 1958. Subsistence agriculture in Melanesia. B.P. Bishop Museum Bulletin 219. Honolulu: Bishop Museum.

Bayliss-Smith, T and E Hviding. 2012. 'Irrigated taro, malaria and the expansion of chiefdoms: Ruta in New Georgia, Solomon Islands'. In Irrigated taro (Colocasia esculenta) in the Indo-Pacific. Biological, social and historical perspectives, edited by M Spriggs, D Addison and PJ Matthews, 219-254. Senri Ethnological Studies no. 78. Osaka: National Museum of Ethnology. 
Bayliss-Smith, T and E Hviding. 2014. 'Taro terraces, chiefdoms and malaria: Explaining landesque capital formation in Solomon Islands'. In Landesque capital: The historical ecology of enduring landscape modifications, edited by T Hakansson and M Widgren, 75-97. Walnut Creek, California: Left Coast Press.

Bayliss-Smith, T and E Hviding. 2015. 'Landesque capital as an alternative to food storage in Melanesia: Irrigated taro terraces in New Georgia, Solomon Islands'. Environmental Archaeology 20 (4):425-436. doi.org/10.1179/1749631414Y.0000000049.

Bayliss-Smith, T, E Hviding and T Whitmore. 2003. 'Rain forest composition and histories of human disturbance in Solomon Islands'. Ambio 32 (5):346-352. doi.org/10.1579/0044-7447-32.5.346.

Bourke, M. 2012. 'The decline of taro and taro irrigation in Papua New Guinea'. In Irrigated taro (Colocasia esculenta) in the Indo-Pacific. Biological, social and historical perspectives, edited by M Spriggs, D Addison and PJ Matthews, 255-264. Senri Ethnological Studies no. 78. Osaka: National Museum of Ethnology.

Bradley, J. circa 1860. A nine month's cruise in the 'Ariel' schooner from San Francisco, in company with the 'Wanderer' of the Royal Yacht Squadron, belonging to Benjamin Boyd Esq. Church Street, Parramatta, New South Wales: J.J. Beukers, General Printer.

Brookfield, HC with D Hart. 1971. Melanesia: A geographical interpretation of an island world. London: Methuen.

Diamond, J. 1997. Guns, germs and steel: A short history of everybody for the last 13,000 years. London: Jonathan Cape.

Hviding, E. 1996. Guardians of Marovo Lagoon: Practice, place and politics in maritime Melanesia. Pacific Islands Monograph Series 14. Honolulu: University of Hawai'i Press.

Hviding, E and T Bayliss-Smith. 2000. Islands of rainforest: Agroforestry, logging and eco-tourism in Solomon Islands. Aldershot: Ashgate. Reprinted 2019, London: Routledge [citations refer to the 2000 edition].

Kirch, P. 1994. The wet and the dry: Irrigation and agricultural intensification in Polynesia. Chicago: University of Chicago Press.

McKinnon, JM. 1975. 'Tomahawks, turtles and traders: A reconstruction of the circular causation of warfare in the New Georgia Group'. Oceania 45 (4):290-307. doi.org/10.1002/j.1834-4461.1975. tb01872.x.

Miller, D. 1979. Solomon Islands national sites survey summary report. Honiara: National Museum.

Purchas, S. [1625] 1906. Hakluytus posthumus or Purchas his pilgrimes in twenty volumes. Vol. 17. Glasgow: James MacLehose \& Sons.

Ribbe, C. 1903. Zwei Jahre unter den Kannibalen der Salamo-Inseln. Dresden-Blasewitz: Hermann Bayer.

Rivers, WHR. 1926. 'Irrigation and the cultivation of taro'. In Psychology and ethnology, edited by G Elliot Smith, 262-287. London: Kegan Paul, Trench, Trubner \& Co.

Roe, D. 2000. 'Maritime, coastal and inland societies in Island Melanesia: The bush-saltwater divide in Solomon Islands and Vanuatu'. In East of Wallace's Line: Studies of past and present maritime cultures in the Indo-Pacific region, edited by S O'Connor and P Veth, 197-222. Rotterdam: Balkema, and Vermont: Brookfield.

Sheppard, PJ, R Walter and T Nagaoka. 2000. 'The archaeology of head-hunting in Roviana Lagoon, New Georgia, Solomon Islands'. Journal of the Polynesian Society 109 (1):9-37.

Shineberg, D (ed.). 1971. The trading voyages of Andrew Cheyne, 1841-1844. Canberra: Australian National University Press. 
Somerville, HBT. 1897. 'Ethnographical notes in New Georgia, Solomon Islands'. Journal of the Royal Anthropological Institute of Great Britain and Ireland 26:357-413. doi.org/10.2307/2842009.

Spriggs, MJT. 1990. 'Why irrigation matters in Pacific prehistory'. In Pacific production systems: Approaches to economic prehistory, edited by DE Yen and J Mummery, 174-189. Occasional Papers in Prehistory 18. Canberra: Department of Prehistory, Research School of Pacific Studies, The Australian National University.

Spriggs, MJT. 2012. 'From Mendana to Riesenfeld: Early account of and speculation on taro irrigation in the Asia-Pacific area'. In Irrigated taro (Colocasia esculenta) in the Indo-Pacific. Biological, social and historical perspectives, edited by M Spriggs, D Addison and PJ Matthews, 1-19. Senri Ethnological Studies no. 78. Osaka: National Museum of Ethnology.

Tedder, M with S Barrus. 1976. 'Old Kusaghe'. Journal of the Cultural Association of the Solomon Islands 4:41-95.

Thomas, T. 2009. 'Communities of practice in the archaeology of New Georgia, Rendova and Tetepare'. In Lapita: Ancestors and descendants, edited by PJ Sheppard, T Thomas and G Summerhayes, 119-145. NZAA Monograph 28. Auckland: New Zealand Archaeological Association.

Thomas, T, PJ Sheppard and R Walter. 2001. 'Landscape, violence and social bodies: Ritualized architecture in a Solomon Islands society'. Journal of the Royal Anthropological Institute NS 7:545-572. doi.org 10.1111/1467-9655.00077.

Walter, R and PJ Sheppard. 2000. 'Nusa Roviana: The archaeology of a Melanesian chiefdom'. Journal of Field Archaeology 27:295-318. doi.org/10.1179/jfa.2000.27.3.295.

Walter, R and PJ Sheppard. 2006. 'Archaeology in Melanesia: A case study from the Western Province of the Solomon Islands'. In Archaeology of Oceania, Australia and the Pacific Islands, edited by I Lilley, 137-159. London: Blackwell. doi.org/10.1002/9780470773475.ch7.

Walter, R and PJ Sheppard. 2017. Archaeology of the Solomon Islands. Dunedin: Otago University Press.

Weightman, B. 1989. Agriculture in Vanuatu: A historical review. Cheam, Surry, UK: British Friends of Vanuatu.

Yen, DE. 1976. 'Agricultural systems and prehistory in Solomon Islands'. In South east Solomon Islands cultural history, RC Green and MM Cresswell, 61-74. Wellington: Royal Society of New Zealand.

Yen, DE. 2009. 'Ethnobotany of the Southeast Solomons cultural history project'. In Lapita: Ancestors and descendants, edited by PJ Sheppard, T Thomas and G Summerhayes, 173-179. NZAA Monograph 28. Auckland: New Zealand Archaeological Association.

\section{Unpublished}

Chikamori, M. 1966. 'Preliminary report on archaeological and ethnological research in the Western Solomon Islands' [in Japanese with English summary]. Tokyo: Kaimedo. Unpublished typescript of summary. In James LO Tedder, Solomon Islands Papers, Pacific Manuscripts Bureau, The Australian National University, PMB 1365, Canberra.

Eto, S. 1968a. 'Interview Holy Mama, description of gardening, March 1968'. Unpublished typescript, pp. 1-3. In James LO Tedder, Solomon Islands Papers, Pacific Manuscripts Bureau, The Australian National University, PMB 1365, Canberra.

Eto, S. 1968b. 'Interview Holy Mama, on gardening, April 1968'. Unpublished typescript, pp. 1-5. In James LO Tedder, Solomon Islands Papers, Pacific Manuscripts Bureau, The Australian National University, PMB 1365, Canberra. 
Page, B. 1964. Bill Page to Margaret Tedder, unpublished letter dated October 30, 1964. In James LO Tedder, Solomon Islands Papers, Pacific Manuscripts Bureau, The Australian National University, PMB 1365, Canberra.

Phillips, FB. 1923. 'Report of the proceedings at Inquiry 34'. Honiara: Solomon Islands National Archives (item missing in 2016). Unpublished notes on Inquiry 34. In James LO Tedder, Solomon Islands Papers, Pacific Manuscripts Bureau, The Australian National University, PMB 1365, Canberra.

Phillips, FB. 1925. 'Land Commissioner's report for native claims 30-37, 50, \&c. (Lever's certificate of occupation, etc.)'. Unpublished. Solomon Islands National Archives, BSIP 18/1/26, Honiara.

Roe, D. 1993. 'Prehistory without Pots: Prehistoric settlement and economy of Northwest Guadalcanal, Solomon Islands'. Unpublished PhD thesis, The Australian National University, Canberra.

Scales, IA. 2003. 'The social forest: Landowners, development conflicts and the state in Solomon Islands'. Unpublished PhD thesis, The Australian National University, Canberra.

Sheppard, PJ, M Busse, C Dureau and J Dodson. 2004. 'Contract UOA312, Annual report 2004'. Unpublished report. Auckland: Department of Anthropology, University of Auckland.

Somerville, HBT. 1893. 'Report concerning the bush in the vicinity of Lihihina Island, Marovo Lagoon, New Georgia, Solomon Islands'. Unpublished report to Commander AJ Balfour, HMS Penguin, pp. 1-10. In Balfour Collection, Royal Geographical Society, London.

Tedder, JLO. 1968. 'Trip into Lupa country up ridge paralleling Hepa River'. Unpublished typescript. In James LO Tedder, Solomon Islands Papers, Pacific Manuscripts Bureau, The Australian National University, PMB 1365, Canberra.

Woodford, CM. 1886. Diary from 4th August 1886 to November 10th 1886. Chas. M. Woodford, F.R.G.S., Gravesend, England. Unpublished. Pacific Manuscripts Bureau, The Australian National University, PMB 1290, Canberra. 
This text is taken from Archaeologies of Island Melanesia: Current approaches to landscapes, exchange and practice, edited by Mathieu Leclerc and James Flexner, published 2019 by ANU Press, The Australian National University, Canberra, Australia.

doi.org/10.22459/TA51.2019.03 